\title{
David Oliver: Can doctors be too politicised?
}

\author{
David Oliver consultant in geriatrics and acute general medicine
}

Berkshire

The Conservative MP Johnny Mercer, a former army officer, is concerned that doctors have become "too politicised." He told the Health Service Journal in December 2018 that he was "really worried" that this politicisation had led to

"unprofessional behaviour" and started to "affect patient care."1 He didn't provide any examples beyond recounting that a GP's child on a school visit had told him, "My daddy says the Tories kill more people than cancer."

I'd like to challenge the notion that doctors can somehow be "too politicised."

Doctors have a long and noble tradition of influencing public policy that affects the public's health. Consider the work of Julian Tudor-Hart, ${ }^{2}$ Douglas Black, ${ }^{3}$ or Michael Marmot on health inequalities ${ }^{4}$; campaigns by doctors on smoking, ${ }^{56}$ clean air, ${ }^{7}$ eradicating tuberculosis, ${ }^{8}$ alcohol policy, ${ }^{910}$ or developing a national dementia strategy, ${ }^{11}$ and evidence based calls to decriminalise drugs. ${ }^{12}$

Medically qualified experts have rightly set out the risks Brexit poses to healthcare provision and public health policy. ${ }^{13}{ }^{14}$ Why shouldn't they?

Doctors have a long and noble tradition of influencing public policy that affects the public's health

This kind of advocacy to improve population health and health services should be central to our values-as essential to our role as the doctor-patient relationship or developing evidence based practice.

It's also surely legitimate for organisations representing doctors to seek to influence or oppose government policy. ${ }^{15}$ The BMA advocates for its members, flags serious problems in the medical workforce, and seeks to shape government policy on NHS funding, priorities, and staffing. As registered charities, medical royal colleges and specialist societies tend to avoid overtly party political positions but have key roles in influencing and shaping policy relevant to healthcare.

Some doctors, such as chief medical officers, ${ }^{16}$ national clinical directors, ${ }^{17}$ or national improvement leads, ${ }^{18}$ also have senior advisory and leadership roles in government and its arm's length bodies. And, as local system leaders in clinical commissioning groups or integrated care systems, doctors have a legitimate role in influencing policy and local politicians. Doctors are also private citizens and have as much right as anyone else to be campaigners, party activists, councillors, or MPs-and to express views on public platforms as stridently as the next person.

Doctors make up the health service's second largest clinical staff group, so they have a stake in an organisation that spends around £124bn of taxpayers' money a year and employs around 1.2 million people. ${ }^{19}$ This group is subject to intense political scrutiny, ministerial oversight, and inter-party debate. Its funding, provision, and performance are intensely political.

I don't know for certain what Mercer meant by "too politicised." My best guess is that he meant "too unionised" and, in particular, "too challenging of government policy." Given that nurses and doctors top the Ipsos MORI table of public trust in professions ${ }^{20}$ - with politicians second bottom-such political challenges are an inconvenient thorn in the side of government. That doesn't mean that we should stop.

Competing interests: See bmj.com/about-bmj/freelance-contributors

Provenance and peer review: Commissioned; not externally peer reviewed.

1 Mclellan A. The bedpan: the army takes values more seriously than the NHS. Health Serv J Dec 2018. https://www.hsj.co.uk/comment/the-bedpan-the-army-takes-values-moreseriously-than-the-nhs-/7023972.article.

2 Tudor Hart J. The inverse care law. Lancet 1971;1:405-12.

10.1016/S0140-6736(71)92410-X. https://www.thelancet.com/journals/lancet/article/ PIIS0140-6736(71)92410-X/fulltext. 4100731

3 Gray AM. Inequalities in health. The Black Report: a summary and comment. Int $J$ Health Serv 1982;12:349-80. https://www.ncbi.nlm.nih.gov/pubmed/7118327. 10.2190/XXMM-JMQU-2A7Y-HX1E 7118327

4 Marmot M. Fair society, healthy lives-the Marmot Review. Feb 2010. www. instituteofhealthequity.org/resources-reports/fair-society-healthy-lives-the-marmot-review/ fair-society-healthy-lives-full-report-pdf.pdf.

5 Royal College of Physicians, UK Centre for Tobacco Control Studies. Fifty years since smoking and health: progress, lessons and priorities for a smoke-free UK. Mar 2012. https://www.rcplondon.ac.uk/file/2547/download?token=KOsndAbc.

6 Royal College of Physicians. What the RCP thinks about tobacco. https://www.rcplondon. ac.uk/projects/outputs/what-rcp-thinks-about-tobacco.

7 Royal College of Physicians. Every breath we take: the lifelong impact of air pollution. 23 Feb 2016. https://www.rcplondon.ac.uk/projects/outputs/every-breath-we-take-lifelongimpact-air-pollution.

8 Cummings KJ. Tuberculosis control: challenges of an ancient and ongoing epidemic. Public Health Rep 2007;122:683-92. 10.1177/003335490712200517. https://www.ncbi. nlm.nih.gov/pmc/articles/PMC1936956/. 17877317 
9 Royal College of Physicians. AHA welcomes minimum alcohol unit price consultation and calls for 50 pence per unit. 28 Nov 2012. https://www.rcplondon.ac.uk/news/aha-welcomesminimum-alcohol-unit-price-consultation-and-calls-50-pence-unit.

10 Royal College of Physicians. What the RCP thinks about alcohol. 1 Feb 2018. https:// www.rcplondon.ac.uk/projects/outputs/what-rcp-thinks-about-alcohol.

11 Department of Health and Social Care. Living well with dementia: a national dementia strategy. 3 Feb 2009. https://www.gov.uk/government/publications/living-well-withdementia-a-national-dementia-strategy.

12 Royal Society for Public Health. Taking a new line on drugs. 2016. https://www.rsph.org. uk/uploads/assets/uploaded/68d93cdc-292c-4a7b-babfc0a8ee252bc0.pdf.

13 McKee M. Martin McKee: Taking stock of Brexit-what comes next? BMJ Opinion 2018 Dec 21. https://blogs.bmj.com/bmj/2018/12/21/martin-mckee-taking-stock-of-brexit-whatcomes-next/.

14 Fahy N, Hervey T, Greer S, et al. How will Brexit affect health services in the UK? An updated evaluation. Lancet 2019 Feb 25. https://www.thelancet.com/journals/lancet/article/ PIIS0140-6736(19)30425-8/fulltext.
15 Moberly T. "We're on the same side, really": medical profession turns to soft power to influence policy. BMJ 2019;364:1707. 10.1136/bmj.1707 30777866

16 McKee M. The changing role of the chief medical officer for England. BMJ2017;356:j1545 $10.1136 / \mathrm{bmj} . j 154528348198$

17 NHS England. National clinical directors. https://www.england.nhs.uk/about/structure/ncd/

18 Getting It Right First Time. Leading clinicians join GIRFT. https://gettingitrightfirsttime.co. uk/leading-clinicians-join-girft/clinical-leads-girft/.

19 House of Commons Library. NHS Key Statistics: England, February 2019. 18 Feb 2019. https://researchbriefings.parliament.uk/ResearchBriefing/Summary/CBP-7281.

20 Ipsos MORI. Ipsos MORI veracity index 2018. Nov 2018. https://www.ipsos.com/sites/ default/files/ct/news/documents/2018-11/veracity_index_2018_v1_161118_public.pdf.

Published by the BMJ Publishing Group Limited. For permission to use (where not already granted under a licence) please go to http://group.bmj.com/group/rights-licensing/ permissions 